\title{
In Vitro Antimalarial Activity and Toxicity of Helianthus annuus L. Leaf Extract against Plasmodium falciparum
}

Nuriha Marangoh ${ }^{1}$, Suciati ${ }^{2}$, Wiwied Ekasari ${ }^{2} *$

${ }^{1}$ Master Program of Pharmaceutical Sciences, Faculty of Pharmacy, Universitas Airlangga, Surabaya, Indonesia

${ }^{2}$ Department of Pharmaceutical Sciences, Faculty of Pharmacy, Universitas Airlangga, Surabaya, Indonesia

*Corresponding author: wiwied-e@ff.unair.ac.id

Submitted: 26 January 2021

Accepted: 6 July 2021

Published: 30 November 2021

\begin{abstract}
Background: Malaria is one of the public health problems in Indonesia. The morbidity rate is still quite high, especially in the eastern part of Indonesia. Objective: This study aimed to determine the inhibitory activity of the leaf extracts of Helianthus annuus L. against Plasmodium falciparum strain $3 D 7$ as well as the cytotoxicity of the extracts. Methods: The leaves of $H$. annuus were extracted by the maceration method with $n$-hexane, chloroform, and ethanol $96 \%$ to increase polarity. The antimalarial assay was performed by using Trager and Jensen method, and the cytotoxicity test was carried out by the MTT method. Results: The results of antimalarial study showed that the chloroform extract had IC 50 value of $0.002 \mu \mathrm{g} / \mathrm{mL}$ and CC $C_{50}$ value of $138.03 \mu \mathrm{g} / \mathrm{mL}, 96 \%$ ethanol extract had an IC $C_{50}$ value of $0.02 \mu \mathrm{g} / \mathrm{mL}$ and $C_{50}$ value of $617.81 \mu \mathrm{g} / \mathrm{mL}$, and $n$-hexane extract had an IC $C_{50}$ value of 1.29 $\mu \mathrm{g} / \mathrm{mL}$ and $C_{50}$ value of $104.89 \mu \mathrm{g} / \mathrm{mL}$. The selectivity index (SI) values of the chloroform, ethanolic, and $n$ hexane extracts were calculated and obtained 69,015.00, 30,890.50, and 81.31, respectively. Conclusion: To conclude, the chloroform extract of $H$. annuus $L$. leaf gave strong antimalarial activity against $P$. falciparum strain $3 D 7$ without any cytotoxicity; therefore, $H$. annuus L. leaf can be a good candidate for the development of an antimalarial drug.
\end{abstract}

Keywords: antimalarial, Helianthus annuus L., Plasmodium falciparum, IC $C_{50}$, cytotoxicity

\begin{abstract}
Abstrak
Pendahuluan: Penyakit malaria merupakan salah satu masalah kesehatan masyarakat di Indonesia. Angka kesakitan penyakit ini masih cukup tinggi, terutama di daerah Indonesia bagian timur. Tujuan: Penelitian ini bertujuan untuk mengetahui aktivitas antimalaria terhadap Plasmodium falciparum strain 3D7 secara in vitro dan uji toksisitas dengan mengunakan ekstrak dari daun Helianthus annuus L. Metode: Daun H. annuus diekstraksi dengan metode maserasi bertingkat cara menggunakan pelarut n-heksana, kloroform dan etanol $96 \%$ secara berurutan. Uji antimalaria dilakukan dengan metode Trager dan Jensen, sedangkan uji toksisitas dengan metode MTT. Indeks Selektivitas (SI) dihitung berdasarkan rasion $\mathrm{CC}_{50} / \mathrm{IC}_{50}$. Hasil: Ketiga ekstrak menunjukkan aktivitas antimalaria, ekstrak kloroform memiliki nilai $\mathrm{IC}_{50} 0,002 \mu \mathrm{g} / \mathrm{mL}$ dan $\mathrm{CC}_{50}$ sebesar $>100 \mu \mathrm{g} / \mathrm{mL}$, ekstrak etanol $96 \%$ memiliki harga $\mathrm{IC}_{50} 0,02 \mu \mathrm{g} / \mathrm{mL}$ dan $\mathrm{CC}_{50}>100 \mu \mathrm{g} / \mathrm{mL}$, dan ekstrak n-heksana memiliki harga $\mathrm{IC}_{50} 1,29$ $\mu \mathrm{g} / \mathrm{mL}$ dan $\mathrm{CC}_{50}>100 \mu \mathrm{g} / \mathrm{mL}$. Hasil perhitungan indeks selektivitas yaitu ekstrak kloroform memiliki SI 69.015,00, ekstrak etanol 96\% memiliki SI sebesar 30,890,50 dan ekstrak n-heksana memiliki SI sebesar 81,31. Kesimpulan: Ekstrak kloroform daun $H$. annuus menunjukkan aktivitas antimalaria paling kuat diantara sampel uji dengan nilai $\mathrm{IC}_{50}$ sebesar $0,002 \mu \mathrm{g} / \mathrm{mL}$, serta menunjukkan bahwa toksisitas yang rendah dengan harga $\mathrm{CC}_{50}$ sebesar $>100 \mu \mathrm{g} / \mathrm{mL}$. Oleh karena itu daun H. аппииs diharapkan dapat dikembangkan menjadi kandidat untuk pengembangan obat antimalaria yang efektif dan aman.
\end{abstract}

Kata kunci: antimalarial, Helianthus annuus L., Plasmodium falciparum, $\mathrm{IC}_{50}$, cytotoxicity 


\section{INTRODUCTION}

Malaria is still considered one of the significant health problems in low and middle tropical countries (WHO, 2016). Malaria is caused by the infection of protozoa from the genus Plasmodium which is transmitted through infected female Anopheles mosquito bites. This disease greatly affects mortality and health, especially in high-risk groups, such as infants, toddlers, and pregnant women, with $45 \%$ to $50 \%$ cases due to Plasmodium falciparum infection (WHO, 2016). As reported annually, Indonesia is one of nine malaria-endemic countries in the South-East Asia region, accounting for $21 \%$ of the region's reported cases and $16 \%$ of malaria deaths (WHO, 2019). Middle and high endemic malaria areas include Papua, West Papua, and East Nusa Tenggara malaria (Department of Disease Control, Ministry of Public Health, 2018).

Antimalarial drugs that exist today are still effective but threatened by increased resistance; for that, plants can be one of the antimalarial drugs that are clinically effective and can be well tolerated so that they can be an essential alternative treatment. One of the plants that can be used is Helianthus annuus L. (sunflower). This plant is from the Asteraceae family and has been scientifically proven to have antimalarial activity. The ethanolic extract of $H$. annuus root showed antimalarial activity with $\mathrm{IC}_{50}$ values of $2.3 \pm 1.4 \mu \mathrm{g}$ ( (Ekasari et al., 2019). However, using the root as a source of antimalarial agents has many obstacles, mainly because it can kill the plant itself. Based on this, the present study continues to examine the antimalarial activity of other parts $H$. annuus, such as the leaves, which have long been used as a traditional antimalarial drug (Muti'ah et al., 2013). Triastutik (2013) reported that the ethyl acetate fraction of $H$. annuus leaf contains sesquiterpenes, and this has been proven by identification using UPLC-MS which shows the presence of artemisinin, heliangolide, linoleic acid, and eupalinolide C (Muti'ah et al., 2013). Sesquiterpenes have been known to have antimalarial activity through the formation of free radicals and destroy vital components of the parasite so that the parasites die (Macias et al., 2002).

Based on the background above, this study focus on the antimalarial activity of three extracts (n-hexane, chloroform, and ethanol) of $H$. annuus leaf against $P$. falciparum strain 3D7. The cytotoxicity study was also conducted to preliminary determine the safety of the extracts (Soh \& Benoit-Vical, 2007).

In addition to activity, data on an ingredient's safety or cytotoxicity is an important part of the research. As a result, a cytotoxicity test was performed on each extract of the test using the MTT assay method, yielding the CC50 value, while the SI value was calculated from the CC50 value to IC50, determining the potential criteria for safe therapeutic extracts to inhibit parasitic growth without cytotoxicity.

\section{MATERIALS AND METHODS Materials}

The solvents used to make $H$. annuus L. leaf extracts were n-hexane (Merck), chloroform (Merck), ethanol 96\% (Merck), ethyl acetate (Merck), $\mathrm{NH}_{4} \mathrm{OH}$, and aquadest. Materials used to make $P$. falciparum culture media and to make in vitro test solutions were aquadest, HEPES buffer (Sigma), RPMI 1640 (Gibco BRL., USA), sodium bicarbonate, gentamicin, plasma, and human erythrocytes, DMSO (Sigma-Aldrich), Giemsa dyes, methanol, and emersion oil.

\section{Plant materials}

The leaves of H. annuus L. were obtained from PT. Megastar Oro-Oro Ombo, Malang, East Java, in November 2016. Materia Medica Batu, East Java identified the sample, and the voucher specimen (number 074/008/101.8/2017) was kept at the Faculty of Pharmacy, Universitas Airlangga. The leaves were airdried at room temperature for seven days. The dried leaves were then grounded before extraction.

\section{Method \\ Extraction}

Extraction was carried out by using the maceration method. Dried leaf powder of H. annuus (500 g) was extracted exhaustively with n-hexane, chloroform, and ethanol to increase polarity. The sample was immersed in the n-hexane for $24 \mathrm{~h}$, followed by filtration to separate the extract and residue. The residue was then re-extracted with $n$-hexane, the procedure was repeated three times for each solvent. The residue was air-dried for 1 - 2 hours to remove any remaining solvent before extraction with the next solvent. All collected filtrates were then concentrated in vacuo to obtain the n-hexane, chloroform, and ethanolic extracts, and the weight of which were $16.45 \mathrm{~g}, 38.48 \mathrm{~g}$, and $31.00 \mathrm{~g}$, respectively.

\section{Antimalarial activity}

$P$. falciparum 3D7 strain (chloroquine-sensitive) were used and cultivated using the Trager and Jensen method (Pandey et al., 1999). Serial concentrations of the extracts that were tested for antimalarial activity were $100 ; 10 ; 1.0 ; 0.1$; and $0.01 \mu \mathrm{g} / \mathrm{mL}$. The antimalarial assay was done in 24 microwell plates with $1 \%$ initial and experimental parasitemia ( $1 \mathrm{~mL} /$ well suspension). It was placed in a candy jar and $\mathrm{CO}_{2}$ incubator at $37^{\circ} \mathrm{C}$ for 48 hours. The incubated materials were then collected 
and used to make a thin smear in a glass slide, fixated in methanol, and stained with $10 \%$ Giemsa. The number of parasites was then observed under a microscope and compared with the negative control to determine the percentage of parasite growth inhibition. The $\mathrm{IC}_{50}$ value was calculated using Probit Analysis.

\section{Cytotoxicity assay}

The cytotoxicity test was carried out by using Huh7it cells at 96 well microplates with a density of $3 \mathrm{x}$ $10^{4}$ cells/well in $100 \mu \mathrm{L} /$ well. The condition of incubation was $5 \% \mathrm{CO}_{2}, 37^{\circ} \mathrm{C}$ for 24 hours. After the incubation, $100 \mu \mathrm{L}$ of extracts were added to each well at concentrations 2000, 1000, 800, 600, 400, 200, 100, $10,1,0.1$, and $0.01 \mu \mathrm{g} / \mathrm{mL}$, followed by incubation for 48 hours. After that, $150 \mu \mathrm{L}$ of MTT solution was added and then absorbance was measured at $560 \mathrm{~nm}$ and 750 nm (Widyawaruyanti et al., 2015)

\section{Data analysis}

Calculation of inhibition concentration $50 \%\left(\mathrm{IC}_{50}\right)$ and cytotoxic concentration $\left(\mathrm{CC}_{50}\right)$ was undertaken using Probit analysis. A regression curve was plotted between the logarithm of sample concentration (x) and the percentage inhibition (y) to obtain a linear regression equation.

\section{RESULTS AND DISCUSSION}

Table 1 showed that all the leaf extracts of $H$. annus had an inhibitory effect against Plasmodium falciparum strain 3D7. The percentage inhibition among the concentration tested revealed a dose dependents effect. The percentage inhibition increased in the higher concentration. The results of the antimalarial study showed that the chloroform extract had an $\mathrm{IC}_{50}$ value of $0.002 \mu \mathrm{g} / \mathrm{mL}, 96 \%$ ethanol extract had an $\mathrm{IC}_{50}$ value of $0.02 \mu \mathrm{g} / \mathrm{mL}$, and $\mathrm{n}$-hexane extract had an $\mathrm{IC}_{50}$ value of $1.29 \mu \mathrm{g} / \mathrm{mL}$.

Chloroform extract of $H$. annuus L. leaf showed the highest inhibitory activity against Plasmodium falciparum which caused malaria, compared to other extracts (Figure 1). Chloroform extract from H. annuus L. leaf had antimalarial activity against $P$. falciparum strain $3 \mathrm{D} 7$ with an $\mathrm{IC}_{50}$ value of $0.002 \mu \mathrm{g} / \mathrm{mL}$.

Table 1. The $\mathrm{IC}_{50}, \mathrm{CC}_{50}$, and SI Values of $H$. annuus L. leaf extracts towards $P$. falciparum strain $3 \mathrm{D} 7$ at 48 hours

\begin{tabular}{cccc}
\hline Samples & $\mathrm{CC}_{50}(\mu \mathrm{g} / \mathrm{mL})$ & $\mathrm{IC}_{50}(\mu \mathrm{g} / \mathrm{mL})$ & Selectivity Index \\
\hline H.annuus n-hexane extract & $104.89 \pm 1.81$ & $1.29 \pm 0.19$ & 81.31 \\
H.annиus Chloroform extract & $138.03 \pm 1.36$ & $0.002 \pm 0.002$ & $69,015.00$ \\
H.annuus Ethanol extract & $617.81 \pm 4.58$ & $0.02 \pm 0.005$ & $30,890.50$ \\
\hline
\end{tabular}

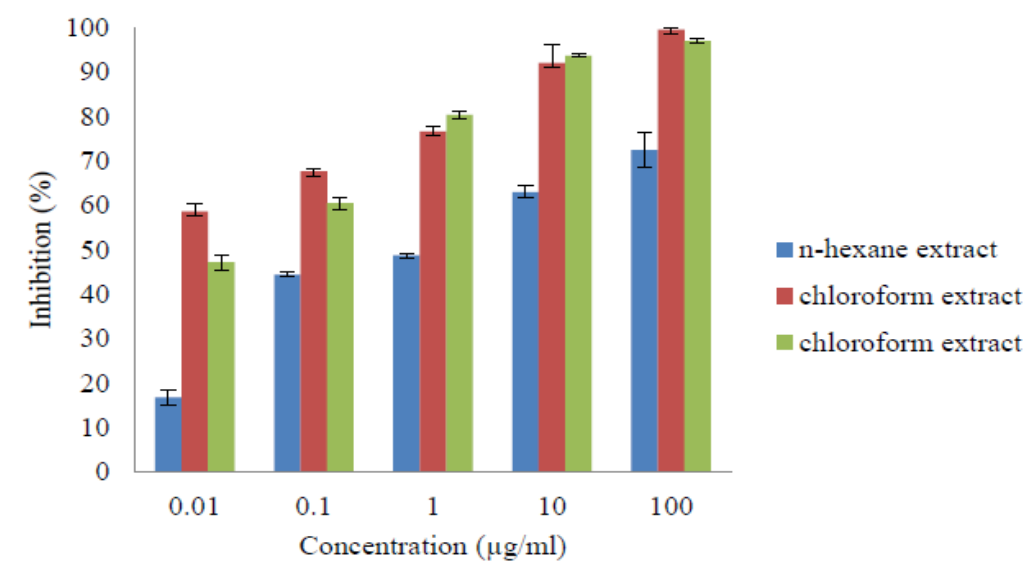

Figure 1. The percentage inhibition of Helianthus annuus L. leaf extract agains Plasmodium falciparum 3D7 strain

Furthermore, to determine the level of safety or cytotoxicity of the test material, the cytotoxicity test was conducted using the MTT assay method. Hepatocyte cells that had been infected with $P$. falciparum would react with the MTT reagent to produce a purple colour which was then absorbed by absorbance at wavelengths of $560 \mathrm{~nm}$ and $750 \mathrm{~nm}$. The cell viability was calculated based on the chloroform extract had $\mathrm{CC}_{50}$ value of $138.03 \mu \mathrm{g} / \mathrm{mL}, 96 \%$ ethanol extract had $\mathrm{CC}_{50}$ value of $617.81 \mu \mathrm{g} / \mathrm{mL}$, and $\mathrm{n}$-hexane extract had $\mathrm{CC}_{50}$ value of P-ISSN: 2406-9388 E-ISSN: 2580-8303
$104.89 \mu \mathrm{g} / \mathrm{mL}$, and chloroform extract had SI of $69,015.00,96 \%$ ethanol extract had SI of 30,890.50 and n-hexane extract had viability percentage compared to the absorbance of the control. Cytotoxicity test results from $H$. annuus L. leaf extract can be seen in Figure 2. In Table 1, according to Peters et al. (1975) and Fadeyi et al. (2013), the cytotoxicity classification of all $H$. annuus L. leaf extracts was reported non-toxic to $P$. falciparum strain $3 \mathrm{D} 7$ with a $\mathrm{CC}_{50}>30 \mu \mathrm{g} / \mathrm{mL}$. 


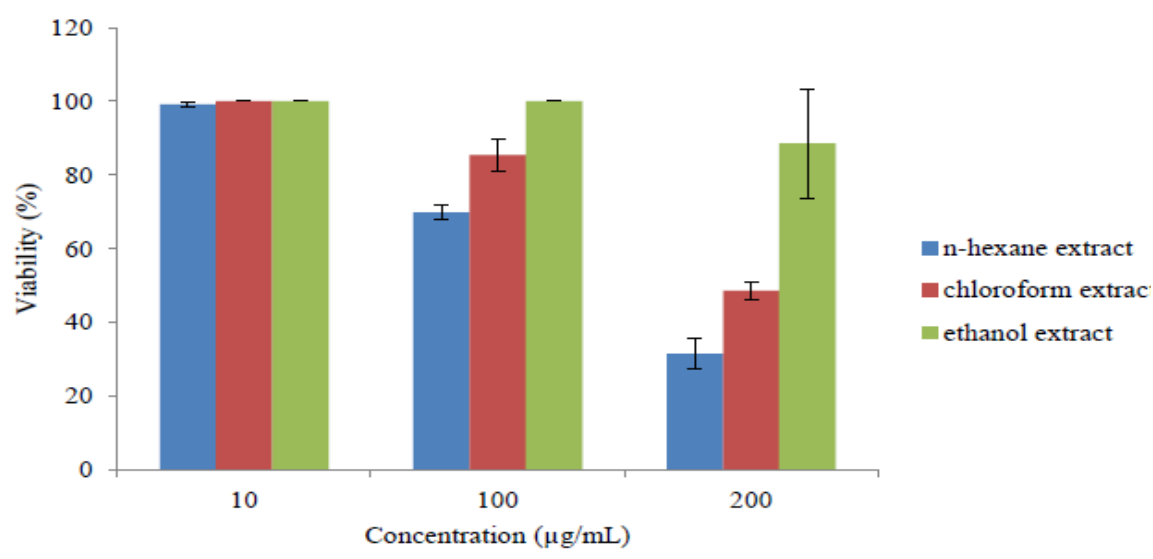

Figure 2. Cytotoxicity test results of Helianthus annuus L. leaf extracts

In Table 1, it could be seen that the $\mathrm{IC}_{50}$ value of Chloroform extract provided the highest antimalarial activity with an $\mathrm{IC}_{50}$ value of $0.002 \mu \mathrm{g} / \mathrm{mL}$ and included in the highly active category $(<0.1 \mu \mathrm{g} / \mathrm{mL}$ ) (Noor, 2007), with $\mathrm{CC}_{50}$ from the chloroform extract of 138.03 $\mu \mathrm{g} / \mathrm{mL}$ and SI 69,015.00. Whereas, the $\mathrm{n}$-hexane extract gave antimalarial activity with an $\mathrm{IC}_{50}$ value of 1.29 $\mu \mathrm{g} / \mathrm{mL}$ so that the active category (>0.1 $\mu \mathrm{g} / \mathrm{mL}$ ) was included (Noor, 2007), and the $\mathrm{CC}_{50}$ value was 617.81 $\mu \mathrm{g} / \mathrm{mL}$, and in the ethanol extract the $\mathrm{IC}_{50}$ value was $0.02 \mu \mathrm{g} / \mathrm{mL}$ and was included in the very active category (Noor, 2007) and $\mathrm{CC}_{50}$ value was $104.89 \mu \mathrm{g} / \mathrm{mL}$.

Antimalarial activity of $H$. annuus L. leaf chloroform extract may be caused by the metabolite in the extract. It was reported that $H$. annuus L. leaf extracted with dichloromethane solvent contain terpenoid class compounds, namely: lactone sesquiterpenes, annuolide E, leptocarpin, bisnorsesquiterpene, Eannuionone, and sesquiterpen L, heliannuol, helibisabonol A (Macias et al., 2002). This is reinforced by the research of Triastutik (2013) that based on the identification of methanol extracts of $H$. annuus L. leaf, it was found the lactone sesquiterpenes compound, while the research of Mutiah et al. (2017) show that in the ethyl acetate fraction it was found artemisinin compound. These two compounds are important components to be effective compounds that can inhibit Plasmodium falciparum 3D7 parasites. Sesquiterpenes have been known to have antimalarial activity through the formation of free radicals and destroy vital components of the parasite so that the parasites die (Macias et al., 2002).

The Selectivity Index (SI) value was calculated as the $\mathrm{CC}_{50}$ value to $\mathrm{IC}_{50}$ in Table 1 shows that all extracts have a good SI value towards $P$. falciparum 3D7. Since all the values of SI were greater than four $(>4)$, they are included in the active category and said that a good value of selectivity index could be a promising drug (Badisa et al., 2009). On the other hand, a high selectivity index can be a safer therapy potential because the selectivity index is introduced as potential extract to inhibit parasitic growth without cytotoxicity (Soh \& Benoit-Vical, 2007).

As a result, it was proposed that the extract can be used to isolate antimalarial compounds in a safe and effective manner. (Kweyamba et al., 2019).

\section{CONCLUSION}

The leaf of Helianthus annuus L. can be a good candidate for antimalarial drug development. The chloroform extract of the leaf possesses the strongest antimalarial activity compared to the n-hexane and ethanol extracts.

\section{ACKNOWLEDGMENT}

This work was supported by "Riset Mandat" of Universitas Airlangga Scheme.

\section{REFERENCES}

Badisa, R. B, Darling-Reed, S. F., Joseph, P., Cooperwood, J. S., Latinwo, L. M. \& Goodman, C. B. (2009). Selective Cytotoxic Activities of Two Novel Synthetic Drugs on Human Breast Carcinoma MCF-7 Cells. Anticancer Research; 29; 2993-2996.

Ekasari, W., Pratiwi, D. W., Amanda, Z., Suciati, Widyawaruyanti, A., Arwati, H. \& Uzor, P. F. (2019). Various Parts of Helianthus annuus Plants as New Sources of Antimalarial Drugs. EvidenceBased Complementary and Alternative Medicine; 2019; 1-6.

Department of Disease Control, Ministry of Public Health. (2018). Malaria Disease Situation in Thailand

(Online). 
https://ddc.moph.go.th/uploads/ckeditor/6f4922f4 5568161a8cdf4ad2299f6d23/files/Malaria/2562/ Malarai\%20w22.pdf. Accessed: 7 June 2019.

Fadeyi, S. A, Fadeyi, O. O., Adejumo, A. A. \& Okoro, C. (2013). In Vitro Anticancer Screening of 24 Locally Used Nigerian Medicinal Plants. BMC Complementary and Alternative Medicine; 79; 19.

Kweyamba, P. A, Zofou, D., Efange, N., Assob, J. C. N., Kitau, J. \& Nyindo, M. (2019). In Vitro and In Vivo Studies on Anti-Malarial Activity of Commiphora africana and Dichrostachys cinerea Used by the Maasai in Arusha Region, Tanzania. Malaria Journal; 119; 1-6.

Macias, F. A., Torres, A., Galindo, L. G., Varela, R. M., Alvarez, J. A. \& Molinillo, J. M. G. (2002). Bioactive Terpenoids from Sunflower Leaves Cv. Peredovick. Phytochemistry; 61; 687-692.

Muti'ah, R., Hayati, E. K. \& Khairunnisak. (2013). The Effectivity of Etanolic Extract Sunflower Leaves (Helianthus annus) as Anti-malarial Agent Against Plasmodium berghei. Proceeding International Conference; 6; 313-320.

Mutiah, R., Badiah, R., Hayati, E. K. \& Widyawaruyanti, A. (2017). Activity of Antimalarial Compounds from Ethyl Acetate Fraction of Sunflower Leaves (Helianthus annuus L.) against Plasmodium falciparum Parasites 3D7 Strain. Asian Journal of Pharmacy and Technology; 7; 61-65.

Noor, R. A., Khozirah, S., Mohd Ridzuan, M. A., Ong, B. K., Rohaya, C., Rosilawati, M., Hamdino, I., Badrul, A. \& Zakiah, I. (2007). Antiplasmodial Properties of Some Malaysian Medicinal Plants. Tropical Biomedicine; 24; 29-35.
Pandey, A. V., Tekwani, B. L, Singh, R. L. \& Chauhan, V. S. (1999). Artemisinin, and Endoperoxide Antimalarial, Disrupts the Hemoglobin Catabolism and Heme Detoxification Systems in Malarial Parasite. Journal of Biological Chemistry; 274; 19383-19388.

Peters, W. J., Portus, H. \& Robinson, B. L. (1975). The Chemotherapy of Rodent Malaria, XXII: the value of Drug-Resistant Strains of P. Berghei in Screening for Blood Schizontocidal Activity. Annals of Tropical Medicine and Parasitology; $69 ; 155-171$.

Soh, P. N. \& Benoit-Vical, F. (2007). Are West African Plants a Source of Future Antimalarial Drugs?. Journal of Ethnopharmacology; 114; 130-140.

Triastutik, Y. (2013). Aktivitas Antimalaria Ekstrak Kasar Seskuiterpen dari Daun Bunga Matahari (Helianthus annuus L.) terhadap Mencit Jantan (Musmusculus). Skripsi; Jurusan Kimia UIN Maulana Malik Ibrahim, Malang.

Widyawaruyanti, A., Khasanah, U., Tumewu, L., Ilmi, H., Hafid, H. A. \& Tantular, I. S. (2015). Antimalarial Activity and Cytotoxicity Study of Ethanol Extract and Fraction from Alectryon Serratus Leaves. International Journal of Pharmacy and Pharmaceutical Sciences; 7; 250253.

World Health Organization (WHO). (2019). World Malaria Report by WHO. https://www.who.int/indonesia/news/detail/2511-2019-title-joint-malaria-programme-reviewreveals-indonesia-is-on-track-for-malariaelimination. Accessed: 7 May 2021.

WHO. (2016). World Malaria Report (Global malaria programme). Geneva: WHO. 